\title{
A comparative study of oral versus intravenous iron in the treatment of moderately anaemic pregnant women
}

\author{
Shivika Gupta*, Ranjana Gupta \\ Department of Obstetrics and Gynaecology, Rohilkhand Medical College and Hospital, Bareilly, Uttar Pradesh, India
}

Received: 21 August 2020

Revised: 07 September 2020

Accepted: 08 September 2020

*Correspondence:

Dr. Shivika Gupta,

E-mail: gupta.shivika@yahoo.com

Copyright: ( $)$ the author(s), publisher and licensee Medip Academy. This is an open-access article distributed under the terms of the Creative Commons Attribution Non-Commercial License, which permits unrestricted non-commercial use, distribution, and reproduction in any medium, provided the original work is properly cited.

\begin{abstract}
Background: Anemia, the decrease of haemoglobin $(\mathrm{Hb})$ concentration is a common disorder complicating pregnancy mostly due to hemodilution, increased demand of iron and poor dietary intake of iron. The aim of this study was to evaluate whether parenteral iron sucrose can be used as an alternative to daily oral iron during pregnancy.

Methods: It was a prospective interventional study conducted in the Department of Obstetrics and Gynaecology, Rohilkhand Medical College and Hospital, Bareilly involving pregnant women at 16-24 weeks with $\mathrm{Hb} 7-10 \mathrm{~g} / \mathrm{dl}$. They were randomly allocated to two groups I and II. Group I (oral group) was given oral iron tablets containing $100 \mathrm{mg}$ of elemental iron and $0.5 \mathrm{mg}$ of folic acid as per therapeutic requirement. Group II (parenteral group) were admitted as day care patients and given a total calculated dose of iron sucrose in divided doses of $200 \mathrm{mg}$ each in $100 \mathrm{ml}$ of normal saline as slow intravenous infusion. $\mathrm{Hb}$, packed cell volume (PCV), blood indices were measured at the start, 2 weeks and 4 weeks of treatment. Any side-effects of treatment were also studied.

Results: A statistically significant increase in values of $\mathrm{Hb}$, hematocrit, reticulocyte count, red blood cells (RBC's) indices: mean corpuscular volume (MCV), mean corpuscular hemoglobin concentration (MCHC) and mean corpuscular hemoglobin $(\mathrm{MCH})$ coupled with no serious side effects with iron sucrose as compared with oral iron.

Conclusions: Intravenous iron sucrose complex is safe, convenient and effective alternative to oral iron for treatment of iron deficiency anemia in pregnancy.
\end{abstract}

Keywords: Anemia, Iron deficiency, Intravenous iron sucrose, Oral iron sulphate, Pregnancy

\section{INTRODUCTION}

Anaemia is the commonest haematological disorder encountered during pregnancy. The overall mean global figure for the incidence of gestational anemia is $25 \%$. World Health Organisation (WHO) has estimated that prevalence of anemia in developed and developing countries in pregnant women is $14 \%$ and $51 \%$ respectively. ${ }^{1.2}$ In India this figure is $65-75 \%$. Anemia is a direct cause of maternal mortality in $20 \%$ of cases and indirect cause in 20 to $40 \%$ of maternal deaths. ${ }^{3}$ In India the prevalence of iron deficiency anemia (IDA) in pregnancy has been reported to be $57.9 \%$ (54.6\% in urban and $59 \%$ in rural) with a wide variation of incidence from state to state. ${ }^{4}$ Anaemia is conventionally defined as low haemoglobin concentration resulting in decrease in oxygen carrying capacity of blood. The Indian Council of Medical Research (ICMR) uses haemoglobin (Hb) of 10.0-10.9 as mild and 7.0 to 10.0 as moderate anaemia. Centre for Disease Control (CDC), United States of America (USA) has defined anaemia as $\mathrm{Hb}$ concentration less than 11 $\mathrm{gm} / \mathrm{dl}$ in the first and last trimester and less than $10.5 \mathrm{gm} / \mathrm{dl}$ in second trimester. WHO defines anaemia in pregnancy as haemoglobin concentration of less than $11 \mathrm{gm} / \mathrm{dl}$ and a haematocrit of less than $33 \%$.

During pregnancy, cardiac output increases by about $40 \%$, which is mainly achieved by increase in stroke volume. 
There is a marked rise in blood volume starting as early as 6 th week of gestation, reaches to maximum of $40-50 \%$ above the pre-pregnant level at 32-34 weeks. The levels remain static thereafter till term. Total plasma volume increase is to the extent of $1.25 \mathrm{~L}$. The red blood cells (RBC) mass is increased to the extent of $20-30 \%$, the increase in RBC volume averages $450 \mathrm{ml}$. This disproportionate increase in plasma volume and $\mathrm{RBC}$ volume leads to a state of hemodilution leading to fall in $\mathrm{Hb}$ concentration and haematocrit. ${ }^{5}$

Total iron requirement during normal pregnancy is estimated to be approximately $1000 \mathrm{mg}$. The amount distributed to fetus and placenta is $300 \mathrm{mg}$. The average increase in erythrocyte volume is $450 \mathrm{ml}$ which requires $500 \mathrm{mg}$ ( $1 \mathrm{ml}$ of erythrocytes contains $1.1 \mathrm{mg}$ of iron). There is obligatory loss of $200 \mathrm{mg}$ of iron through various normal excretory routes. The iron in placenta and fetus is permanently lost during delivery. These losses are by way of bleeding from placental site, episiotomy, lacerations or lochia. However there is saving of about $300 \mathrm{mg}$ of iron due to amenorrhoea of 10 months ( 1 cycle - $30 \mathrm{mg}$ average loss). ${ }^{6}$

The iron need is not evenly distributed throughout the pregnancy but mostly limited to the third trimester. Considering the daily needs, this means approximately 0.8 $\mathrm{mg} /$ day iron is needed in first trimester, $4-5 \mathrm{mg}$ /day in the second trimester and about $6-7 \mathrm{mg} /$ day iron in the third trimester. As iron absorption is less than $10 \%$, so for a minimum of 4-5 mg absorption, at least $40-60 \mathrm{mg}$ of iron should be available in diet. Diet alone cannot supply such amounts of iron especially in developing countries. Hence iron supplementation is a necessity for all pregnant women. ${ }^{5}$

Once the diagnosis of iron deficiency anemia and its cause is made, a therapeutic approach is planned, there are three major approaches - red cell transfusion, oral iron therapy and parenteral iron therapy. Although oral iron is the ideal therapy for management of iron deficiency anaemia in pregnancy, but due to impaired iron absorption, failure to deliver tablets, low tolerability, poor compliance and side effects, it is not as effective. Also it takes several weeks to raise $\mathrm{Hb}$ and months to replenish iron stores in the body. Though as an alternative, parenteral iron preparations are available and it helps to overcome the problem of compliance of patient by giving the total required dose over a short interval, along with replenishing the iron stores, but mostly is reserved for patients in whom oral therapy fails. Parenteral iron therapy includes intramuscular iron dextran, iron-sorbitol-citric acid complex or intravenous iron sucrose, and ferric carboxymaltose. Iron sucrose is reported to be safest and most widely used. Red cell transfusion therapy is reserved for those individuals who have symptoms of severe anemia, cardiovascular instability, and continued and excessive blood loss, and those who require immediate intervention.
The objective of the study was to evaluate whether parenteral iron sucrose can be used as an alternative to daily oral iron during pregnancy for management of anaemia.

\section{METHODS}

This was a randomized prospective interventional study conducted in the department of Obstetrics and Gynaecology, Rohilkhand Medical College and Hospital, Bareilly, Uttar Pradesh, India for the period of one year (i.e. November 2017 to October 2018) after approval by the institutional ethical committee. The study group consisted of 100 women with singleton pregnancy between 16-24 weeks with $\mathrm{Hb}$ 7-10 gm/dl (moderate anaemia ICMR classification). Women with $\mathrm{Hb}<7 \mathrm{gm} / \mathrm{dl}$ or $\mathrm{Hb}>10 \mathrm{gm} / \mathrm{dl}$, multiple pregnancy, any medical disorder tuberculosis (TB)/diabetes mellitus (DM)/thyroid/ liver/kidney disease, any obstetrical complications, allergic reaction to any preparation of iron and women who have taken any form of iron therapy for anaemia during present pregnancy were excluded from the study.

A detailed history followed by general physical, systemic and obstetrical clinical examination of all cases was carried out based on a preformed proforma. Baseline laboratory investigations like $\mathrm{Hb}$, packed cell volume (PCV), mean corpuscular volume (MCV), mean corpuscular hemoglobin $(\mathrm{MCH})$, mean corpuscular hemoglobin concentration (MCHC), peripheral smear, urine routine examination, and stool for ova/cyst were carried out before commencing the study. Any other investigations were done as and when required. Tablet albendazole $400 \mathrm{mg}$ was given at the beginning of the study to all the patients. Then they were randomly allocated to two groups I and II.

Group I oral group - was given oral iron tablets containing $100 \mathrm{mg}$ of elemental iron and $0.5 \mathrm{mg}$ of folic acid as per the therapeutic requirement of the case. Group II parenteral group - was admitted as day care patients and given a total calculated dose of iron sucrose in divided doses of $200 \mathrm{mg}$ each in $100 \mathrm{ml}$ of normal saline as slow intravenous infusion over 45 minutes at weekly intervals.

Dose of iron sucrose calculated as: Pre-pregnant body weight $(\mathrm{kg}) \times($ target $\mathrm{Hb}-$ initial $\mathrm{Hb})(\mathrm{g} / \mathrm{dl}) \times 2.5+500$ mg.

These patients continued taking $0.5 \mathrm{mg}$ folic acid tablets throughout pregnancy. Follow-up evaluation of haematological parameters was done, $\mathrm{Hb}$ and reticulocyte reviewed on day 7, followed by $\mathrm{Hb}, \mathrm{PCV}, \mathrm{MCV}, \mathrm{MCH}$ and MCHC done at 2 weeks, 4 weeks of starting the therapy. During each visit clinical improvement and adverse effects were also noted. Peripheral smear and serum iron studies were done as and when indicated.

Data obtained was analyzed using Statistical Package for the Social Sciences (SPSS) version 23 and suitable 
statistical tests will be applied to attain inference. Five percent (5\%) probability level was considered as statistically significant i.e. $\mathrm{p}<0.05$.

\section{RESULTS}

On inclusion, the two groups were comparable in terms of demographic, biologic and hematologic parameters (Table 1). The mean age of women on inclusion in intravenous group was $25.92 \pm 4.20$ years with mean $\mathrm{Hb}$ of $8.17 \pm 0.61$ $\mathrm{g} / \mathrm{dl}$ and mean hematocrit of $24.09 \pm 2.47 \%$. In the oral group, mean age was $24.98 \pm 3.91$ years with, mean $\mathrm{Hb}$ $8.42 \pm 0.74 \mathrm{~g} / \mathrm{dl}$, and mean hematocrit was $25.06 \pm 2.81 \%$. Most patients had pre-conceptional anemia.

Table 1: Baseline demographic and hematologic parameters of antenatal women.

\begin{tabular}{|llll|}
\hline Parameter & $\begin{array}{l}\text { Group I } \\
\text { (oral) }\end{array}$ & $\begin{array}{l}\text { Group II } \\
\text { (i.v.) }\end{array}$ & $\begin{array}{l}\text { P } \\
\text { value }\end{array}$ \\
\hline Age (years) & $24.98 \pm 3.91$ & $25.92 \pm 4.20$ & NS \\
\hline Parity & Multi & Multi & NS \\
\hline $\begin{array}{l}\text { No of unbooked } \\
\text { patients }\end{array}$ & $58 \%$ & $64 \%$ & NS \\
\hline $\begin{array}{l}\text { Pre-conceptional } \\
\text { anemia }\end{array}$ & $66 \%$ & $52 \%$ & NS \\
\hline $\begin{array}{l}\text { Hemoglobin } \\
\text { (g/dl) }\end{array}$ & $8.42 \pm 0.74$ & $8.17 \pm 0.61$ & NS \\
\hline PCV (\%) & $25.06 \pm 2.81$ & $24.09 \pm 2.47$ & NS \\
\hline $\begin{array}{l}\text { Reticulocyte } \\
\text { count (\%) }\end{array}$ & $0.80 \pm 0.27$ & $0.76 \pm 0.28$ & NS \\
\hline
\end{tabular}

Table 2: Actual Hb levels over 4 weeks.

\begin{tabular}{|llll|}
\hline & $\begin{array}{l}\text { Hb } \\
\text { (baseline) } \\
(\mathrm{g} / \mathrm{dl})\end{array}$ & $\begin{array}{l}\text { Hb at 2 } \\
\text { weeks } \\
(\mathrm{g} / \mathrm{dl})\end{array}$ & $\begin{array}{l}\text { Hb at } 4 \\
\text { weeks } \\
(\mathrm{g} / \mathrm{dl})\end{array}$ \\
\hline Group I & $8.43 \pm 0.74$ & $9.20 \pm 0.78$ & $10.70 \pm 1.12$ \\
\hline Group II & $8.17 \pm 0.61$ & $10.24 \pm 0.59$ & $11.27 \pm 0.69$ \\
\hline P value & & $<0.001$ & $<0.001$ \\
\hline
\end{tabular}

An increase in $\mathrm{Hb}$ was observed from baseline to 4 weeks in each group, but increase in $\mathrm{Hb}$ in intravenous iron sucrose group was more than oral group at each point of measurement $(p=0.000)$ as shown in Table 2 . The difference in $\mathrm{Hb}$ values from baseline in the intravenous group was $2.07 \pm 0.02$ at 2 weeks, $2.18 \pm 0.865$ at 4 weeks, compared to oral iron, which is $0.77 \pm 0.04$ at 2 weeks, $3.1 \pm 0.08$ at 4 weeks. $\mathrm{p}<0.001$ which was clinically significant and showed that the $\mathrm{Hb}$ levels were increased more in the intravenous group.

Table 3: Actual values of haematocrit.

\begin{tabular}{|llll|}
\hline & $\begin{array}{l}\text { Hematocrit } \\
\text { (baseline) } \%\end{array}$ & $\begin{array}{l}\text { Hematocrit } \\
\text { at } 2 \text { weeks }\end{array}$ & $\begin{array}{l}\text { Hematocrit } \\
\text { at 4 weeks }\end{array}$ \\
\hline Group I & $25.07 \pm 2.86$ & $26.68 \pm 2.81$ & $30.75 \pm 2.98$ \\
\hline Group II & $24.09 \pm 2.47$ & $29.67 \pm 2.46$ & $32.18 \pm 2.53$ \\
\hline P value & & $<0.001$ & $<0.001$ \\
\hline
\end{tabular}

In the present study, an increase in mean hematocrit was observed from $25.06 \pm 2.81 \%$ to $26.68 \pm 2.86$ at 14 days to $30.75 \pm 2.98 \%$ at 4 weeks post treatment in oral group. In i.v. group, an increase in mean hematocrit was noted from $24.09 \pm 2.47 \%$ to $29.67 \pm 2.46$ at 14 days to $32.18 \pm 2.53 \%$ at 4 weeks post treatment (Table 3 ).

Table 4: Comparison of rise in reticulocyte count.

\begin{tabular}{|c|c|c|c|c|c|c|c|}
\hline \multicolumn{4}{|c|}{ Group I (oral) } & \multicolumn{4}{|c|}{ Group II (i.v.) } \\
\hline $\begin{array}{l}\text { Reticulocyte } \\
\text { count }(\%)\end{array}$ & Mean & $\begin{array}{l}\text { Standard } \\
\text { deviation }\end{array}$ & $P$ value & $\begin{array}{l}\text { Reticulocyte } \\
\text { count }(\%)\end{array}$ & Mean & $\begin{array}{l}\text { Standard } \\
\text { deviation }\end{array}$ & P value \\
\hline At baseline & 0.80 & 0.27 & \multirow{2}{*}{$<0.001 *$} & At baseline & 0.76 & 0.28 & \multirow{2}{*}{$<0.001 *$} \\
\hline At 14th day & 1.78 & 0.56 & & At 14th day & 3.52 & 1.02 & \\
\hline
\end{tabular}

*statistically significant

Table 5: Comparison of rise in blood indices.

\begin{tabular}{|c|c|c|c|c|c|c|c|}
\hline & \multicolumn{3}{|c|}{ Group I (oral) } & \multicolumn{4}{|l|}{ Group II (i.v.) } \\
\hline Variables & Mean & $\begin{array}{l}\text { Standard } \\
\text { deviation }\end{array}$ & $P$ value & Variables & Mean & $\begin{array}{l}\text { Standard } \\
\text { deviation }\end{array}$ & $P$ value \\
\hline MCV (fl) at baseline & 70.92 & 7.31 & \multirow{2}{*}{$\begin{array}{l}<0.001 \\
*\end{array}$} & MCV (fl) at baseline & 72.36 & 4.56 & \multirow{2}{*}{$\begin{array}{l}<0.001 \\
*\end{array}$} \\
\hline MCV (fl) at 4th week & 82.97 & 7.55 & & MCV (fl) at 4th week & 86.26 & 5.55 & \\
\hline MCH (pg) at baseline & 24.65 & 3.19 & \multirow{2}{*}{$\underset{*}{<0.001}$} & MCH (pg) at baseline & 24.06 & 2.42 & \multirow{2}{*}{$\begin{array}{l}<0.001 \\
*\end{array}$} \\
\hline MCH (pg) at 4th week & 29.55 & 3.32 & & MCH (pg) at 4th week & 30.62 & 1.71 & \\
\hline MCHC (g/dl) at baseline & 29.55 & 2.71 & \multirow{2}{*}{$\begin{array}{l}<0.001 \\
*\end{array}$} & $\begin{array}{l}\text { MCHC (g/dl) at } \\
\text { baseline }\end{array}$ & 29.71 & 1.76 & \multirow{2}{*}{$\begin{array}{l}<0.001 \\
*\end{array}$} \\
\hline $\begin{array}{l}\text { MCHC (g/dl) at 4th } \\
\text { week }\end{array}$ & 34.70 & 2.24 & & $\begin{array}{l}\mathrm{MCHC}(\mathrm{g} / \mathrm{dl}) \text { at } 4 \text { th } \\
\text { week }\end{array}$ & 34.84 & 2.01 & \\
\hline
\end{tabular}


Table 6: Side effects of oral iron $(n=50)$.

\begin{tabular}{|lll|}
\hline Side effects & Number & Percentage \\
\hline Nausea/vomiting & 2 & 4 \\
\hline Abdominal pain & 1 & 2 \\
\hline Constipation & 10 & 20 \\
\hline Diarrhea & 1 & 2 \\
\hline Metallic taste & 6 & 12 \\
\hline No side effects & 30 & 60 \\
\hline Total & 50 & 100 \\
\hline
\end{tabular}

Table 7: Side effects of i.v. iron $(n=50)$.

\begin{tabular}{|lll|}
\hline Side effects & Number & Percentage \\
\hline Gastro-intestinal & Nil & Nil \\
\hline Allergic reactions & 2 & 4 \\
\hline Hypotension & Nil & Nil \\
\hline Dizziness & 1 & 2 \\
\hline Anaphylactic reaction & Nil & Nil \\
\hline No side effects & 47 & 94 \\
\hline Total & 50 & 100 \\
\hline
\end{tabular}

There was a significant rise in serum reticulocyte levels from baseline to 4 weeks in both groups, but the increase in intravenous group was more than oral group at each point of measurement $(\mathrm{p}=0.000)$ as shown in Table 4 .

In the present study highly statistical significant difference was observed in mean $\mathrm{MCV}, \mathrm{MCH}$ and $\mathrm{MCHC}$ at 14 days after treatment $(\mathrm{p}<0.001)$ and at 4 weeks post treatment $(\mathrm{p}=0.015)$ between the two groups (Table 5).

There were no serious adverse drug reactions recorded. There were no episodes of anaphylaxis or hypotensive shock. $2 \%$ patients had dizziness and $4 \%$ patients had mild allergic reaction with i.v. sucrose as compared to oral group where mostly patients experienced gastrointestinal tract (GIT) symptoms like $20 \%$ patients had constipation, $12 \%$ had metallic taste, $4 \%$ had nausea and vomiting, $2 \%$ had diarrhoea and $2 \%$ had abdominal pain which lead to non-compliance with oral iron (Table 6 and 7).

\section{DISCUSSION}

Iron deficiency anemia affects about $18 \%$ of women during pregnancy in industrialized countries while in nonindustrialized countries prevalence varies between 35$75 \%$ with the average being $56 \%$. The prevalence of anemia in India in year among women of reproductive age group (15-49 years) was $51.40 \%$ as of $2016 .^{7}$

Interventions are often designed to prevent the decrease in hemoglobin concentration and the decline in iron stores associated with pregnancy and postpartum which includes both public health and therapeutic approaches. The public health approaches of education and iron fortification have had great success in some developed countries in reducing the prevalence of anemia in women of reproductive age. A therapeutic approach to iron supplementation, rather than a public health - based approach, is used throughout much of the world but suffers from real, or perceived, problems of compliance. Long term oral treatment can produce side effects and associated with increased oxidative damage which can lead to non-compliance and difficulty in monitoring. Parenteral administration by intramuscular injection is a painful alternative with a variable degree of efficacy. Intravenous iron treatment with iron sucrose is associated with better efficacy, rapid store recovery, better compliance, safety and a short hospital stay.

In the present study, an increase in mean hemoglobin was observed from $8.42 \pm 0.74 \mathrm{~g} / \mathrm{dl}$ at start of treatment to $9.20 \pm 0.78 \mathrm{~g} / \mathrm{dl}$ at 14 days, and to $10.70 \pm 1.12 \mathrm{~g} / \mathrm{dl}$ at 4 weeks after treatment in oral group and from $8.17 \pm 0.61$ $\mathrm{g} / \mathrm{dl}$ at the start of treatment to $10.24 \pm 0.59 \mathrm{~g} / \mathrm{dl}$ at 14 days and to $11.27 \pm 0.69 \mathrm{~g} / \mathrm{dl}$ at 4 weeks after treatment in i.v. group. There was highly statistically significant difference noted in mean $\mathrm{Hb}$ at 14 days and at 4 weeks post treatment between the two groups $(\mathrm{p}<0.0000)$.

In a study by Momen et al (1996) done on pregnant women with gestational age less than 32 weeks, iron sucrose group obtained significantly higher levels of $\mathrm{Hb}$ as compared with the oral iron group. ${ }^{8}$ The increase in $\mathrm{Hb}$ was from $758 \pm 7.9 \mathrm{~g} / 1$ to $128.5 \pm 6.6 \mathrm{~g} / 1$ in i.v. group when compared to increase in $\mathrm{Hb}$ from $766 \pm 7.8 \mathrm{~g} / 1$ to $111.4 \pm 12.4 \mathrm{~g} / 1$ in oral group $(\mathrm{p}=0.001)$ after treatment. This study is comparable to our study in that $\mathrm{Hb}$ concentration was higher in the intravenous group in a shorter period of time.

In a study by Deeba et al, the difference in $\mathrm{Hb}$ values from baseline in the intravenous group was $1.72 \pm 0.484$ at 2 weeks, $2.18 \pm 0.865$ at 4 weeks, $2.89 \pm 0.5989$ at 6 weeks compared to oral iron, which was $0.5750 \pm 0.456$ at 2 weeks, $1.39 \pm 0.4402$ at 4 weeks, and $1.9 \pm 0.3020$ at 6 weeks. ${ }^{9} \mathrm{P}$ value was 0.000 which was clinically significant and showed that the hemoglobin levels were increased more in the intravenous group.

In the present study, an increase in mean hematocrit was observed from $25.06 \pm 2.81 \%$ to $26.68 \pm 2.86 \%$ at 14 days to $30.75 \pm 2.98 \%$ at 4 weeks post treatment in oral group. In i.v. group, an increase in mean hematocrit was noted from $24.09 \pm 2.47 \%$ to $29.67 \pm 2.46 \%$ at 14 days to $32.18 \pm 2.53 \%$ at 4 weeks post treatment. There was improvement in both the groups but more significant improvement was noted in i.v. group which may be due to better absorption and compliance in i.v. group. These results were consistent with study conducted by Abhilasini et al. ${ }^{10}$

Determination of the numbers of reticulocytes or immature RBCs that still retain RNA provides useful information about the bone marrow's capacity to synthesize and release red cells in response to physiologic challenge, such as anemia. Reticulocyte count at the end of 2 and 4 weeks was significantly higher in i.v. iron group indicating improvement, quicker response of haemopoietic system to intravenous iron, and formation of new RBCs. These 
results were consistent with study done by Neeru et al and Kochhar et al. ${ }^{11,12}$

Haematological parameters $\mathrm{MCH}, \mathrm{MCV}, \mathrm{MCHC}$ also had faster rise and higher values in i.v. iron group in comparison to oral group.

Gastrointestinal side-effects were about $40 \%$ in the oral group, while the reported incidence varied from negligible to $31 \%$ in other studies. Mild adverse events noted in the i.v. group were vomiting, rashes and giddiness following first dose of iron sucrose. Other studies reported allergic reactions and fever, which were not observed in the present study. ${ }^{13,14}$ In studies done in pregnancy by Bayoumeu et al and $\mathrm{Al}$ Momen et al, no serious side effects were observed with iron sucrose as compared to oral iron. ${ }^{8,15}$ The only adverse reactions reported by the patients were mild fever unpleasant taste during injection. Because there were no serious adverse drug reactions and no episodes of anaphylaxis, we feel that it is safe for anemia in pregnancy.

\section{CONCLUSION}

Intravenous iron therapy is a safe alternative for the treatment of anemia, being able to reduce the need for blood transfusion and its concomitant side effects such as anaphylactic shock, febrile and hemolytic reactions, infections (hepatitis B, C, HIV, protozoan and bacterial) alloimmunization and graft versus host disease. During pregnancy and puerperium it helps to rebuild iron stores, the symptoms of anemia to subside at a faster rate and reduces the risk of developing anemia in subsequent pregnancies. Major advantages are safety, efficacy, compliance and cost-effectiveness in an outpatient setting.

Funding: No funding sources

Conflict of interest: None declared

Ethical approval: The study was approved by the Institutional Ethics Committee

\section{REFERENCES}

1. Worldwide prevalence of anaemia 1993-2005. World Health Organization (WHO) Global Database on Anaemia. Switzerland. 2008. Available at: https://www.who.int/nutrition/publications/micronutr ients/anaemia_iron_deficiency/9789241596657/en/. Accessed on 20 May 2020.

2. WHO global database on child growth and malnutrition. Geneva: WHO programme on nutrition. 1997. Available at: https://www.who.int/ nutgrowthdb/en/. Accessed on 20 May 2020.

3. Centre for disease control and prevention. Recommendations to prevent and control iron deficiency in the United States. Morbidity Mortality Weekly Report. 1998;47:1-29.
4. National family health survey (NFHS-3). Ministry of health and family welfare (Government of India). 2005-2006. Available at: http://rchiips.org/NFHS/nfhs3.shtml. Accessed on: 20 May 2020.

5. Cunningham FG, Leveno KJ, Bloom SL, Spong CY, Dashe JS, Hoffman BL, et al. William Obstetrics: 24th edition. Maternal Physiology. 2014.

6. Pritchard JA. Changes in the blood volume during pregnancy and delivery. Anesthesiol. 1965;26:393.

7. World Health Organization. WHO Global Database. Geneva: WHO, 2015. Available at: https://www.who.int/gho/publications/world_health_ statistics/2015/en/. Accessed on 20 May 2020.

8. Al-Momen AK, Meshari AA, Al-Nuaim L, Saddique A, Abotalib Z, Abbas M. Intravenous iron sucrose complex in treatment of iron deficiency anemia during pregnancy. Euro J Obstet Gynaecol Reprod Biol. 1996;69:121-4.

9. DeebaShafi, Purandare SV, Sathe AV. Iron deficiency anaemia in pregnancy: Intavenous vs. oral route. J of Obstet Gynaecol India. 2012;62(3):317-21.

10. Abhilasini GD, Sangili H, Rani R. Intravenous iron sucrose and oral iron for the treatment of iron deficiency anaemia in pregnancy: J Clin Diagnostic Res. 2014;8(5):4-7.

11. Neeru S, Nair NS, Rai L. Iron Sucrose Versus Oral Iron Therapy in Pregnancy Anemia. Indian J Community Med. 2012;37:214-8.

12. Kochhar PK, Kaundal A, Ghosh P. Intravenous iron sucrose versus oral iron in treatment of iron deficiency anemia in pregnancy: a randomized clinical trial. $\mathbf{J}$ Obstet Gynaecol Res. 2013;39(2):504-10.

13. Kriplani A, Mahey R, Dash BB, Kulshreshta V, Agarwal N, Bhatla N. Iron Sucrose therapy for anaemia Indian J Med Res. 2013;138:78-82.

14. Sharma JB, Jain S, Mallika S, Singh T, Kumar A, Arora R. A Prospective, partially randomised study of pregnancy outcomes and haematologic responses to oral and parenteral iron in tratmet of moderately anaemic pregnant women. Am J Clin Nutr. 2004;79:116-22.

15. Bayoumeu F, Subiran-Buisset C, Baka NE, Legagneur H, Monnier-Barbarino P, Laxenaire MC. Iron therapy in iron deficiency anemia in pregnancy: intravenous route versus oral route. Am J Obstet Gynaecol. 2002;186:518-22.

Cite this article as: Gupta S, Gupta R. A

comparative study of oral versus intravenous iron in the treatment of moderately anaemic pregnant women. Int J Reprod Contracept Obstet Gynecol 2020;9:3972-6. 